Article

\title{
Do Independent Fiscal Institutions Enhance Parliamentary Accountability in the Eurozone?
}

\author{
Cristina Fasone \\ Department of Political Science, LUISS University, Italy; E-Mail: cfasone@luiss.it
}

Submitted: 1 March 2021 | Accepted: 6 July 2021 | Published: 13 August 2021

\begin{abstract}
Independent fiscal institutions (IFIs) have been established or reformed in all eurozone countries following the reform of economic governance. As they are expected to counter the deficit bias of the governments and the information asymmetry of the legislatures and the public over the management of the budget, IFIs may support or even strengthen parliamentary accountability. This hypothesis is tested with regard to three IFIs, the Irish Fiscal Advisory Council, the Italian Parliamentary Budget Office, and the Spanish Independent Authority for Fiscal Responsibility. Although the economic context in which the IFIs were created was similar in the three eurozone countries, as was their mandate, these institutions have a rather different institutional positioning, being within the Parliament, in Italy; within the Executive, in Spain; and a stand-alone body in Ireland. This is likely to influence the IFIs' contribution to parliamentary accountability and we hypothesize that the closer the position of an IFI and its contacts to the parliament, the stronger is the scrutiny of the executive on budgetary policies. The analysis of parliamentary questions, hearings, and of the activation of the 'comply or explain' procedures shows that, overall, the IFIs' potential role to enhance parliamentary accountability has remained underexploited by the three legislatures, with no significant differences as for the institutional positioning of the IFI.
\end{abstract}

\section{Keywords}

European economic governance; independent fiscal institutions; Ireland; Italy; parliamentary accountability; Spain

\section{Issue}

This article is part of the issue "Rising to a Challenge? Ten Years of Parliamentary Accountability of the European Semester" edited by Eric Miklin (University of Salzburg, Austria), Aleksandra Maatsch (University of Wroclaw, Poland) and Tomasz P. Woźniakowski (Hertie School, Germany).

(C) 2021 by the author; licensee Cogitatio (Lisbon, Portugal). This article is licensed under a Creative Commons Attribution 4.0 International License (CC BY).

\section{Introduction}

Ten years after the reform of European economic governance, its medium-term implications on democratic accountability are still to be explored to a large extent. Scholars have analysed at length the effects of the new European fiscal and economic rules on parliaments and have shown diverging views in this respect (Woźniakowski et al., 2021). At the same time, investigation into the new independent fiscal institutions (IFIs), the non-majoritarian technocratic bodies established or reformed under EU law after the eurozone crisis, and their impact on parliamentary activity within the economic governance procedures, is still very limited and at an early stage (see Fasone \& Griglio, 2013, pp. 264-265; Horvath, 2018, p. 504).
As a consequence of the reinforced 'two-level game' that characterizes the policy-making in the post-crisis governance (Crum, 2018, pp. 273-274), between the national and the supranational levels of government, the problem of information asymmetry already faced by domestic parliaments is further worsened by the difficulty to place clear responsibilities for the decisions taken, even though the executives still remain the main interlocutors for legislatures. Taking stock of these problems and aiming to restore fiscal sustainability, EU legislative acts-and provisions of the Fiscal Compact (Article 3.2)-were introduced to make the setting up of national IFIs mandatory by the end of 2013 (EU Directive 2011/85). Great discretion is left to Member States as for the design, organisation, and powers of IFIs. Article 2 of EU Regulation 473/2013-applicable to eurozone 
countries only-lists the basic features IFIs should have, including a statutory regime provided by law, independence from the budgetary authorities and public and private bodies, appointment of their members based on competence and expertise, access to information and adequate resources to fulfil their role, and a capacity to communicate publicly and in a timely manner.

Under Article 5 of this Regulation, IFIs shall ensure the compliance of the national budgetary processes with numerical fiscal rules incorporating Member States' medium-term objectives (MTO) and, in general, with the deficit and debt rules set out in the EU Treaties and legislation. 'Where appropriate,' they also provide public assessments with respect to national fiscal rules, and they evaluate whether there are conditions to activate the correction mechanism; if it is employed they also determine if the correction is proceeding in accordance with national rules and plans, as well as if any of the circumstances allowing the temporary deviation from the MTO have arisen or ceased. While nothing is added in EU law as for their relationship with parliaments, the latter could benefit from the information produced and the assessment published by IFIs in the budgetary domain.

This article focuses on the effects of the setting up and functioning of IFIs on parliamentary accountability, post-crisis. It seeks to answer the following research question: Has the creation of IFIs in the eurozone, in the framework of the post-crisis economic governance, indirectly contributed to enhancing parliamentary accountability at the national level? Indeed, it is hypothesized here that: 1 ) the reports, the opinions and the assessments published by IFIs, particularly if directly transmitted to the parliaments, can support their ability to hold the governments accountable; and that 2) the closer is an IFI to the parliament, the more the parliamentary scrutiny on the executive is likely to be strengthened. The article first investigates the complex relationship between parliamentary accountability and IFIs in the new economic governance. It then offers a comparative analysis of the contribution of the Irish Fiscal Advisory Council (IFAC), the Italian Parliamentary Budget Office (IPBO), and the Spanish Independent Authority for Fiscal Responsibility (AIReF) in relation to parliamentary accountability in the three domestic contexts. The article highlights that legislatures in the selected countries have exploited IFIs' activity only to a limited extent to enhance the scrutiny procedures of the executive and that such an outcome does not appear to be strongly influenced by the institutional positioning of the IFI.

\section{Parliamentary Accountability and Independent Fiscal Institutions in the Post-Crisis Economic Governance}

Elaborating on Bovens' definition (2007, p. 447), in parliamentary systems parliamentary accountability refers to the relationship between an executive and a parliament, in which the executive has an obligation to explain and justify its conduct; the parliament has the ability to pose questions and pass judgments; and the executive may face consequences, typically of a political nature, including forced resignation. As such, accountability is managed by parliaments by seeking to obtain information and explanations from the executive on its policies as well as by asking the government to adjust and correct its action, if needed, even by threatening to use or impose sanctions (Auel, 2007, p. 500; Woźniakowski et al., 2021).

The simple existence of IFIs may lead to an enhancement of parliamentary accountability given the two objectives they aim to pursue: to counter the deficit bias of the government and to re-balance the information asymmetry on budgetary issues (Beetsma \& Debrun, 2016, pp. 4-9; Hagemann, 2011, p. 77; Tesche, 2019, pp. 1211-1212). Acting with a short-term perspective, one of electoral cycles to seek re-election, governments are typically keen to increase expenditure and reduce taxes to please the electors with immediate benefits, thereby expanding the deficit (Viney \& Poole, 2019, pp. 444-447). Although this may not be the case in the so-called 'frugal' countries which are used to following tight fiscal discipline as the main direction of political economy, with little variation in relation to the government in office. The parliament and its majority can be more or less cooperative with the government to second the strategy of deficit spending. By providing an autonomous and authoritative public assessment of the executive's fiscal and budgetary policies, of their sustainability and long-term impact, in principle, the IFIs make it possible for the parliament and especially for the opposition to use their reports, briefings, and opinions as benchmarks with which the government's information can be checked; if need be, the reliability and desirability of the latter for the national political economy can be contested based on a technical, non-partisan, and expert account. The government may thus be prompted to take a different course of action and to revise its estimates, according to the IFI's position and following MPs' directions. The detection by an IFI of a violation of the deficit and debt rules may trigger a 'comply or explain' procedure, whereby the government is compelled to appear in front of the parliament to justify its choice, to adjust its position, or to explain why it does not intend to follow the IFI's advice (Fromage, 2017, p. 137-138).

Also, the second function fulfilled by IFIs, to tame the executive dominance over financial and economic information (Tesche, 2019, p. 1217; Viney \& Poole, 2019, p. 447), can be instrumental to improving parliamentary scrutiny and accountability. As well known, Dicey's view on the centrality of the parliamentary scrutiny of the budget (Dicey, 1885/2013, pp. 171-175) has in reality long been outdated (Bateman, 2020, pp. 3-15; Ruiz Almendral, 2017, pp. 27-28). The quasi-monopoly of the information on the budget in the hands of the national Treasuries have traditionally made it difficult for the legislatures to gain accurate control of the government's estimates and to ground their assessment on independent 
information, especially for parliaments devoid of a strong administrative apparatus. The situation is further worsened in the EU context and in the eurozone in particular, given that there are 'too many executives' to control in principle (Curtin, 2014, p. 4) and that the diluted responsibilities in economic governance decisionmaking do not help to foster streamlined and effective procedures of parliamentary control and scrutiny (Crum, 2018 , p. 280). In contrast to this trend, the rise of IFIs at the domestic level, with the solid expertise of their members on economic and fiscal matters, could be used as independent and non-partisan benchmark for parliamentary debates, providing an autonomous assessment not just on the national fiscal and macroeconomic figures offered by the government, but also on the European fiscal stance.

Although the EU has followed a minimalist approach on the institutional configuration of IFIs, even in eurozone countries, the way EU law has been interpreted by the European Commission (hereafter, the Commission) hints at the fact that IFIs are conceived as enablers of parliamentary accountability as well as being independent watchdogs meant to contribute to fiscal sustainability. The Commission has repeatedly warned Member States against the threat of IFls lacking independence and autonomy from the budgetary authorities. Overly close ties of an IFI with the executive have been criticised by the Commission not only in relation to authorities that were evidently 'agents' of the Government, such as the Polish Supreme Audit Office after 2015, but also concerning IFIs set up within the executive, even if they enjoyed a certain autonomy, such as in Belgium (European Commission, 2017, pp. 9-10). By the same token, the Commission has regularly recommended that Member States provide for 'comply or explain' procedures in parliament whenever the estimates, forecasts, and figures produced by the government do not reflect those of the IFI or are considered unrealistic by it (European Commission, 2012, point 7).

In the EU, most IFIs were established within the executive, though being functionally independent, or as stand-alone bodies. Their members are usually nominated by the government or the government is in charge of the final appointment (Closa et al., 2020, pp. 24-26). As long as they are equipped with independent staff and resources, sufficient to fulfil their tasks, with an autonomous mandate protected by law (regardless of whether it is enshrined in a statutory provision or in a governmental regulation), and they are granted access to information, the relationship of the IFIs with the executive is not problematic from the viewpoint of the independence from the budgetary authorities, according to the Commission. Yet, on the one hand, the relationship with the parliament is considered by Horvath (2018, pp. 511-513) as one of the seven indicators composing the IFIs' "aggregate scrutiny effectiveness index," next to the breadth of the mandate, financial resources, human resources, access to information, public awareness, and reaction from government. This hints at the importance of contacts and exchanges between the IFIs and parliamentary bodies and MPs as the democratic place par excellence where fiscal choices are made. On the other hand, we may expect that the institutional positioning of an IFI can impact accountability procedures in parliament. Without this jeopardising their independence, IFls that are hosted within parliamentary institutions, i.e., parliamentary budget offices, may be in a better position to enable the legislatures to fulfil enhanced scrutiny of the government than those set up within the executive, as stand-alone institutions, or are attached to the court of auditors and to a central bank. Of course, the IFIs' institutional 'embedding' in terms of proximity to the parliament can vary depending on the appointment procedures, the frequency of the contact, especially if mandated by law, and on the consequences of the IFI's activity on the government (e.g., how the 'comply or explain' procedure is activated and with which consequences for the legislature).

From this elaboration on parliamentary accountability and on the rationales for the setting up of IFIs, two guiding hypotheses can be derived. First, the technical and non-partisan information provided by the IFIs can enable the legislatures to pose better-informed questions and to pass more accurate judgments on the budgetary decisions taken by the government, thereby forcing the executive to publicly explain (as well as to parliament) any deviation from the IFI's assessment, and if need be, to correct its action. Second, regarding the IFIs' positioning, it can be expected that when such an institution takes the form of a parliamentary budget office, the collaboration between the IFI and the legislature can allow the Parliament to make the most of the information flow deriving from the IFI to control the government and to use the 'comply or explain' procedure as a further accountability tool compared to the case of a standalone fiscal council or an IFI established within the executive, with its looser relationship with the legislature.

\section{Research Design}

\subsection{Analytical Framework}

To assess if and to what extent parliamentary accountability has been (positively) affected by the work of IFIs (first hypothesis) three main variables are to be assessed. First of all, the frequency and the issues covered by the hearings of IFIs' members in parliament are investigated, treating hearings as a tool to get information on the fiscal soundness of the executive policies and for the legislature to develop an independent evaluation of the government's performance. Indeed, these hearings can provide parliament with an invaluable and independent source of information to control and, if need be, challenge the government. This assessment is carried out comparing what the legislative provisions foresee with their implementation in practice as it can be that the legislatures 
effectively use hearings of IFI's members to collect information or, instead, this tool is seldom activated.

Second, the absolute number of parliamentary questions and the number of questions citing or quoting IFIs' evidence are initially compared as a rough indicator of whether opinions, reports, and statements of fiscal councils are managed by MPs as (new) benchmarks to scrutinize the government, thereby prompting the executive to provide clarifications and explanations. Relatedly, to offer a more fine-grained analysis, an account of the number and topics covered by parliamentary questions citing the IFIs' assessment and the respective replies provided by the government to them is offered. This way it can be detected whether the IFI's activity is able to indirectly enrich the parliamentary debate on fiscal policies and target the potential deficiencies and pitfalls of the governmental choices, forcing the executive to take responsibility for them and better justify its decisions.

Third, the 'impact' of IFIs' assessment on parliamentary accountability is tested with regard to the design and practice of the 'comply or explain' procedure, whereby the government can be called to explain publicly why it intends to deviate from the IFI's recommendations and evaluation or if it is willing to conform. The procedure is established post-crisis in most eurozone countries and special consideration will be given to the direct involvement of the parliament in such a procedure (which may either trigger it or act as the forum in front of which the government has to explain its firm commitment to deviate from the IFI's position) and to the actual use of it, notably, whether the deviation goes unnoticed by the legislature and if the government prefers to comply or confirm its standpoint giving due justifications for that.

The influence of IFIs on parliamentary accountability can also vary depending on the type of legislature we look at. Parliamentary scholars have elaborated a number of typologies, for example, considering the main focus of their activity, debating or policy-making (Polsby, 1975); combining their institutional powers with the level of public support (Mezey, 1979, p. 23); or zooming into the category of the 'reactive' legislatures to rank their 'policy-influencing' capacity, based on their level of institutionalization, linked to the development of their internal organization and structure (Norton, 1990, pp. 143-152). Considering the budgetary powers of parliament specifically, it seems worth looking at Wehner's ranking of national legislatures for what concerns their ability to shape the budget (Wehner, 2010, pp. 45-48): Crucial factors in this respect are deemed to be formal and substantive amendment powers of the parliament; the consequences stemming from the parliamentary refusal to approve the budget by the end of the fiscal year; executive flexibility during the implementation of the budget; time for scrutiny; committee capacity; and access to budgetary information, which is linked to the prospective role of IFIs. Parliaments are then ranked in between the extreme of Westminster-style legislatures with very little influence on the budget to the opposite end of the most influential budgetary authority, the US Congress (Wehner, 2010, pp. 60-63). Although in the $\mathrm{EU}$ and in the eurozone, in particular, the adoption of supranational fiscal rules and the operation of a common budgetary timeline has probably made national parliaments more comparable as budgetary authorities than they used to be-they act within similar overarching constraints-differences can still be detected in their ability to control the formation and the execution of the budget (Fasone, 2014, pp. 6-10; Markakis, 2020, pp. 130-141).

The strength of the budgetary powers of a legislature may be affected by the choice of the specific positioning of an IFI within or outside the parliament (second hypothesis). Indeed, if, according to Wehner (2010, pp. 50-51), access to budgetary information is one of the key variables determining the strength of a parliament as a budgetary authority, then the easier it is for a legislature to retrieve such information, the better. Without disregarding the requirement that IFIs be functionally autonomous, the frequency of contact and the regular collaboration between a legislature and a parliamentary budget office, in principle, makes this latter model of fiscal council be the one that is best suited to enhance information flow in favour of the Parliament, compared to a stand-alone fiscal council or to an IFI placed within the executive.

\subsection{Case Selection}

The contribution of IFIs to parliamentary accountability is assessed in three eurozone countries, Ireland, Italy, and Spain, countries which are (traditionally) associated with limited levels of compliance with EU deficit and debt rules and which were beset by serious financial troubles during the euro crisis. The choice is explained by the fact that only eurozone Member States are bound to apply stricter budgetary rules and to comply with EU Regulation $473 / 2013$ (by contrast, non-euro area countries have to establish IFIs, but are not expected to abide by the requirements in terms of institutional design and mandate as per the 'Two-Pack' Regulation). Moreover, Ireland, Italy, and Spain were amongst the most affected countries during the debt crisis and they received either financial assistance (Ireland and Spain) or support (Italy). Thus, not only were they probably interested in re-gaining fiscal sustainability and financial credibility-which IFIs are expected to support (Bertelsmann, 2013, pp. 75-76)-but also their parliaments had been significantly marginalised in the adoption of euro-crisis measures (Moschella, 2017, pp. 253-257). Therefore, the same legislatures could have seen the newly established IFIs, set up between 2012-2014, as allies to strengthen parliamentary accountability.

According to the SIFI index developed by the Commission to measure the independence and scope of action of IFIs in the EU, the IFAC, the IPBO, and the 
AIReF are amongst the most independent fiscal institutions from the budgetary authorities in the euro area (Closa et al., 2020, pp. 33-34; European Commission, 2021). In addition to this, based on the roles that can be assigned to them, the Irish, the Italian, and the Spanish IFIs are also amongst the EU IFIs equipped with the broadest mandate (Closa et al., 2020, pp. 37-38; Jankovics \& Sherwood, 2017, p. 15).

The three IFIs, however, are rather different regarding their institutional 'embedding.' The IPBO is a collegial body placed within the parliament and has strong ties to the legislature, both in the appointment process and in its functioning (Law no. 243/2012, Article 16, para 2). The AIReF is a monocratic body placed at the Ministry of Budget and Public Administration though enjoying organisational and functional autonomy from the executive (Ley Organica 6/2013, Articles 1 and 7). Finally, the IFAC is a stand-alone collegial IFI (Irish Parliament, 2012, Part 3), a 'child of the crisis,' which Ireland was demanded to establish in the memorandum of understanding so that it could benefit from the rescue programme in 2011 (Closa et al., 2020, p. 17).

The budgetary powers of the three legislatures, not by chance, are rather different. While the Irish Parliament resemblances the Westminster model of a legislature with a very marginal influence on the budget (Maatsch, 2017, p. 697), the Italian Parliament has traditionally shown a remarkable 'transformative capacity' over the budget, also thanks to its strong committee system, though remaining rather weak in the ex-postcontrol over the budget (Griglio, 2020, pp. 209-210). The Spanish Parliament stands somewhat in between the two, getting closer to the Italian legislature regarding committee capacity and ability to shape the content of the budget, but leaning toward the Irish Parliament regarding its limited access to budgetary information (Wehner, 2010, pp. 60-63), at least prior to the setting up of the AIReF.

The differences in these IFIs' relationship with the parliament are patent already in the appointment process. The three members of the IPBO are appointed by agreement between the Presidents of the Senate and of the Chamber of Deputies and are chosen from a list of 10 candidates prepared by the standing committees competent on public finance, each one deciding by two-thirds majority. In contrast, the involvement of the Spanish Parliament in the appointment of the AIReF's President is more limited. The President is appointed by the Council of Ministers, upon proposal by the Minister of the Budget and of Public Administration. The Committee on the Budget of the Spanish Congress then invites the appointee for hearings and votes, on behalf of the Congress and by absolute majority, for its appointment. Thus, although this has never happened so far, the Congress could reject the appointee. Unlike the other two cases, there is no involvement of the Parliament in the appointment of the five IFAC's members by the Minister of Finance, but they can be removed from office for misconduct by the lower house, the Dáil Éireann.

The significant differences in the institutional positioning of the three IFIs, which otherwise show similar features concerning their level of independence and the breadth of mandate, allows one to assess whether such a diverse institutional configuration affects the IFIs' contribution to enhancing parliamentary accountability.

The timespan covered by the analysis refers to the last two years (2019-2020), so as to include the parliamentary activities before and after the Covid-19 outbreak; to consider the change in the membership of the IFAC (both in 2019 and 2020) and the AIReF (in 2020); change in the composition of the governments in Ireland (from a minority government led by Fine Gael to a majority coalition government between Fianna Fáil, Fine Gael, and the Greens since 2020); in Italy (with the shift since September 2019 from a coalition government between the 5SM and Lega to a coalition between the 5SM, the Democratic Party, and other minor centre-left political allies); and in Spain, which experienced two national elections in 2019 (with the PSOE leading a minority government in crisis first and then a coalition government with Podemos). Given the confidence relationship in place, the investigation is limited to lower houses, the Dáil Éireann, the Italian Chamber of Deputies, and the Spanish Congress.

The research was carried out through a textual analysis of primary sources, i.e., reports, opinions, and recommendations issued by the IFIs, transcripts of parliamentary hearings and of debates, both in committee and in plenary, the texts of parliamentary questions, and the governmental responses, retrieved on the websites and the databases on the parliaments selected. Moreover, the investigation is complemented by the findings extracted from secondary sources, ranging from the relevant literature to the databases and reports on the IFIs curated by the Commission and the OECD.

\section{Parliamentary Accountability at Work via Independent Fiscal Institutions}

\subsection{Parliamentary Hearings}

The legislation in the three countries makes it compulsory for the IFIs to appear in front of the parliament, under certain conditions. Article 11, para 2, of the Schedule annexed to the Irish Fiscal Responsibility Act 2012 requires the IFAC chairperson to be heard in front of the committees about the activity of the IFI whenever requested to do so by these parliamentary bodies. Article 24, para 8, of the Ley Orgánica 6/2013 states that the AIReF's President shall appear in front of the competent parliamentary committees at least once a year. More detailed is Article 18 of Italian law no. 243/2012 according to which the President of the IPBO is to be heard by the parliamentary committees dealing with public finance at their request and to present them with 
the annual programme of the IFI's activities. Moreover, the IPBO drafts opinions and reports for the parliamentary committees on their demand.

In practice, the appearance of the IFAC's members in front of the Dáil Éireann's committees has not been very frequent and this has triggered a debate on whether it might have been appropriate to move the IFIs closer to or even inside the Parliament (Downes \& Nicol, 2016, p. 69). In the end, the IFAC's position has not been changed, but in 2018 the Irish legislature-in particular its select committee on budgetary oversight-was equipped with a parliamentary budget office, which being part of the Oireachtas' administration, is not considered an IFI under EU law by the Commission (though appearing in the IFIs' OECD database). Hearings of the IFAC's members and staff are organised by the select committee on budgetary oversight on average three times per year, for the pre-budget report; during the budget process; and at the year's end, in preparation of the new fiscal year. This is what also happened in 2019, while in 2020 IFAC's representatives were heard just once, on 16 June 2020, by the special committee on the response to the Covid-19 pandemic to evaluate the aptness of the governmental recovery policies to react to the pandemic. From the verbatim reports of the hearings, a very cautious approach of the IFAC's members in answering the questions posed by MPs can be detected. Recalling that the IFAC's mandate allows it to comment only on the overall fiscal stance and not to express its view on specific tax measures, spending items, or priorities, the Irish IFI tried to show self-restraint whenever the debate in the committee aimed somewhat to 'politicise' the IFAC's position expressed in reports and opinions.

The frequency of the hearings is certainly not higher in Spain. Also due to the elections held in 2019, the then President of the AIReF, José Luis Escrivá, was only heard on 29 January, to present the IFI's report on the budget law for 2019, compared to the 2-3 parliamentary hearings that had been organized every year until then. In 2020, the new AIReF's President, Cristina Herrero, who took office in March, was heard three times: on 4 June 2020, in front of the Budget Committee on the use of the escape clause and the deviation from the MTO by the Government (which require the approval by the two Houses of the Cortes by absolute majority and the endorsement by AIReF) which she supported; on 16 June, by the Committee for the social and economic recovery, on the governmental strategy to counter the Covid-19 crisis; and on 5 November, in front of the Committee on revenues for an assessment of the budget bill for 2021. Despite the modest number of hearings that had taken place, in 2020 only there were 12 requests by MPs (compared to 23 issued over the period 2016-2019) to organise such hearings, plus a request by the Committee for the social and economic recovery to AIReF to draft a report on the post-pandemic economic situation and potential ways out: A sign that in the Spanish Parliament the information provided by the
AIReF is perceived as an important tool with which to scrutinize the executive.

Compared to the IFAC and the AIReF, the appearance of the IPBO's President in the Chamber of Deputies is much more frequent and systematic. He was heard in front of the Budget Committee of the Chamber (although this is usually a joint hearing by the Budget Committees of the two Houses) 9 times in 2019 and 11 times in 2020. Besides the occasion of the presentation of the IFI's annual work programme, the hearings were the opportunity for an in-depth analysis by MPs of the strengths and weaknesses of the Document of Economics and Finance (which also includes the Stability Programme and the National Reform Programme), of its revision during the year, and of the repeated requests and related governmental reports seeking the parliamentary authorisation to deviate from the MTO (as in Spain, the approval is to be voted by an absolute majority in each House).

\subsection{Parliamentary Questions}

From time to time the reports, projections, and recommendations of the three IFIs are cited or quoted in parliamentary questions to the government (oral and written, in committee, and in plenary), to seek explanations and justification for its action.

Looking just at the numbers may appear misleading. It is much more interesting to consider how the citation of the IFls' reports and recommendations has affected the 'dialogue' between MPs and the government through the questions. In Spain, following what was said on the hearings, it is confirmed that the questions citing the IFIs' evidence to obtain clarifications from the Government came exclusively from opposition members. For example, in the written question No. 184/19573 of 24 July 2020, MPs from the group VOX asked whether the Executive intended to take any action as a followup to the AIReF's spending review report on the governmental program. In response, the Government engaged with the explanation of the methodology used in that report, considered that the AIReF had not properly appreciated the outcomes of the 2013 reform to the said program, and it also provided clear indications on how it had tried to implement the critical observations of the IFI. A series of questions (184/19444, 184/19465, $184 / 19468,184 / 19473$ of 23 July 2020) with similar contents were addressed by MPs from Partido Popular, Ciudadanos, and VOX on the measures the Executive was willing to adopt following the AIReF's recommendations on the execution of the budget in 2020 . The Government thus explained its plans for the medium-term national fiscal strategy to ensure financial sustainability, the adaptations needed for the Stability and National Reform Programmes for 2020, and the importance to adopt the Investment and Reform Plan as soon as possible so as to be able to take advantage of EU funds.

Both in Ireland and Italy, parliamentary questions drawing on IFIs' evidence are predominantly asked by 
Table 1. Citations of IFIs in parliamentary questions.

\begin{tabular}{lccc}
\hline & Irish Dáil Éireann & Italian Chamber of Deputies & Spanish Congress \\
\hline Total number of questions (2019-2020) & 19,720 & 16,325 & 31,178 \\
$\begin{array}{l}\text { Number of questions where the evidence } \\
\text { provided by the IFI are cited }\end{array}$ & 52 & 8 & 28 \\
\hline
\end{tabular}

members of opposition groups, though not exclusively. The questions asked by Irish MPs ranged from requests for clarifications regarding the precise nature of the relationship between the Minister of Finance and the IFAC (whether the latter cooperates with the Minister and how it can provide guidance; see question $49136 / 18$ by deputy Michael Moynihan, Fianna Fáil, in 2019) to the Government's compliance with the IFAC's critical review. For instance, on 26 September 2019, Deputy Thomas P. Broughan (Independent) asked how the Government would have responded to the IFAC's criticism regarding the lack of credibility of the medium-term plan for the 2020 budget. The Minister of Finance, Paschal Donohoe, explained the reasons for the disagreement with the IFAC, linked to the expenditures' ceilings, and defended the executive's projections of the expenditures' growth rate for the period 2020-2024. On 29 September 2020, Deputy Richard Bruton (Fine Gael) and Deputy Gerald Nash (Labour Party) asked two similar questions to the Minister of Finance about the governmental position on the IFAC's advice on the future budget, in particular on the additional stimulus that needs to be added. These oral questions triggered a well-informed and respectful discussion between the Minister and the two Deputies (one from the majority and one for the opposition) on the spending priorities to be foreseen in light of the pandemic and of Brexit. In these circumstances, it appears that the background information and assessment provided by the IFAC enhanced the quality of the parliamentary debate and let MPs discuss the complex economic and financial developments with greater precision.

In the Italian Chamber of Deputies such a level of debate, triggered by the IPBO's observations, has not characterised the question time in the period considered. On some occasions, the findings presented in the reports of the IPBO were used by the MPs to ask oral or written questions to the Executive, alongside similar data provided by other independent authorities or public administrations (see, e.g., A.C. oral question no. 3-00537 tabled on 19 February 2019 by deputies for the Democratic Party, then in opposition; and A.C. written question no. 4-06635 tabled on 30 August 2020 by deputies of the $5 \mathrm{SM})$. In the few cases where parliamentary questions did cite the IPBO's position, the IFI's assessment was used as the basis to ask the executive for clarifications. For example, the oral question no. 3-00920, put forward on 30 July 2019 by deputies from the Five Star Movement to the then Minister of Finance, Giovanni Tria, relied on the projections of the IPBO to look for information about the governmental measures planned to contain the negative effects of the passive interest rates on the public debt for the period 2020-2021. Likewise, on 22 October 2020, oral question no. 3-01834, presented by opposition MPs from Forza Italia quoted the IPBO's critical assessment of the forecasts for the period 2022-2023, asking the Government to clarify how it intended to mitigate the uncertainty linked to the financing (according to the draft budgetary plan for 2021) of a significant part of the 2022 and 2023 budgets through fiscal feedback whose final volume was hard to predict.

\subsection{The 'Comply or Explain' Procedures}

A potential 'enabler' of parliamentary accountability through the use of IFIs' reports and opinions is the 'comply or explain' procedure, also recommended by the Commission. The procedure is foreseen in the three countries but with a different level of involvement of the legislature and is variously applied in practice. In Italy, the 'comply or explain' procedure is triggered by Parliament: When the IPBO expresses an assessment that significantly deviates from that of the executive, at least one-third of the members of the committee dealing with public finance can ask the Government to explain the reasons why it wishes to confirm its position or, instead, it can adjust it to the IPBO's recommendations (Law no. 243/2012, Article 18, para 3).

In Ireland, if the Government "does not accept an assessment of the Fiscal Council" in relations to any matters under its jurisdiction, the Minister shall "prepare and lay before Dáil Éireann a statement of the Government's reasons for not accepting it" within two months of being given a copy of this evaluation (Irish Parliament, 2012, Article 8, para 6). In Spain, however, the 'comply or explain' procedure does not foresee the participation of the Parliament. The AIReF delivers recommendations to all public administrations, including to the regional and local authorities. If the targeted administration, for example, the Government or one of its Ministries, does not intend to comply, then it needs to publicly explain its reasons (Ley organica 6/2013, Article 5). The AIReF publishes a report collecting the recommendations and all the responses from the public administrations every quarter. The recommendations are addressed both to the substance of the measures adopted and, most of all, to problems of transparency of the administration concerned (Kasperskaya \& Xifré, 2018, pp. 65-69). In particular, the majority of them typically deal with difficulties faced by the AIReF in accessing information and data requested from the administration, including to the 
Government (OECD, 2018), who in the past had tried to act as a filter between the administration and the AIReF (Fromage, 2017, p. 133). The AIReF's reports of the last two years show that the situation has substantially improved. Although some explanations by the executive still remain elusive and vague, the Government is more responsive and committed to following the IFI's recommendations. For example, in the AIReF's report on the third trimester published on 26 November 2020, of the five recommendations issued during the previous months, four of them had been already implemented by the Government or were in the process of being implemented. This notwithstanding, the Parliament is not involved in the procedure: Some of the AIReF's recommendations are discussed during the hearings of the President and, occasionally, the Government is challenged on the matter when relevant parliamentary questions are asked or during plenary debates, but the 'comply or explain' process occurs outside the Parliament.

The situation is different in Ireland and Italy, where the starting of a 'comply or explain' procedure is not a frequent event. The IFAC has repeatedly challenged the reliability of the figures and the forecasts provided by the Government in the past (European Fiscal Board, 2017, p. 35). Although the Executive has not always responded to the IFI's criticism nor has it always adjusted its proposals to it, in 2016 its negative opinions on the governmental projections for deficit and debt, defined as unrealistic (in the Fiscal Assessment Reports of November 2015 and 2016), triggered an ad hoc debate with the Government in the Parliament and the subsequent re-adaptation of the projections for the budget of 2017. The procedure has not been formally triggered since then, although the Government regularly responds to the IFAC's reports and on a number of occasions the Executive has de facto engaged in the Parliament to justify the divergence in its position with the IFAC: In 2019 and 2020 during the question time, in hearings or parliamentary debates, and in a few cases it has been also asked by MPs for its responses.

In Italy, the IPBO has very often 'challenged' the overly optimistic forecasts of the Government on which the budget was modelled compared to the macroeconomic situation. The 'comply or explain' procedure was activated by the budget committees of the Italian Parliament just once in 2016, as well as on another occasion, in 2018, when the IPBO explicitly objected to the governmental fiscal policy. In 2016, it validated the macroeconomic and budgetary forecasts for 2017 with a series of critical observations. In the framework of a parliamentary hearing, the IPBO President explained the reasons for such a position and, following these concerns, the Ministry of Finance subsequently revised the forecasts. In 2019 and 2020, there was no lack of critical opinions from the IPBO, especially during the budget session for 2020, but the opposition groups did not use the procedure under Article 18 of Law no. 243/2012.

To sum up, the 'comply or explain' procedure toward the Government has been regularly used in Spain, where the Parliament is not directly involved. By contrast, in Ireland and Italy where parliamentary participation in the process is guaranteed, it has been seldom activated.

\section{Conclusions}

The Irish, the Italian, and the Spanish parliaments have started to make use of reports and opinions produced by the respective IFIs since their setting up. The latter have indirectly contributed to reducing the information asymmetry vis-à-vis the governments. Thus, dealing with the first research hypothesis, the IFIs' activity has significantly enhanced the access of the three legislatures (the lower chambers, in particular, which have been the targets of the empirical analysis) to budgetary information, indirectly improving their scrutiny capacity. However, no significant advancement can be detected, as a consequence of the fiscal councils' operation, in the ability and willingness of these chambers to pass judgments of the executive's fiscal policy and to prompt the government to justify or correct its conduct. As such, a trend can be detected in the three systems under review: It does not appear that there is a clear relationship between the strength of the budgetary powers of these legislatures however affected they have been by the reform of the European economic governance, and the prospective benefits fiscal councils have for enhancing parliamentary accountability.

Moving on to assess the second hypothesis, the institutional positioning of IFIs, within or outside the parliament, has implications on the overall volume and frequency of hearings of the IFI's members in front of parliamentary committees. This positioning was much higher with regard to the IPBO than was the case for the stand-alone IFAC and the AIReF which was established within the executive. Yet the number of parliamentary questions citing the evidence provided by the IPBO to control the government is quite limited, as it is in the Irish and in the Spanish contexts. In the three legislatures, the opposition MPs have been keener than the majority members, especially during the pandemic year, to use IFIs reports and opinions to hold the government accountable.

The 'comply or explain' procedure, despite being strongly recommended by the Commission, has been marginally exploited by the legislatures (including by opposition groups) regardless of the IFI's institutional positioning. In Ireland and Italy the 'comply or explain' procedure, which in both cases foresees the involvement of the parliament, was not enforced in 2019-2020 nor did the government promptly adjust itself to the IFIs' positions. By contrast, in Spain, the publication by AIReF of all its recommendations to the Government and the public administrations as well as their follow-up has improved accountability of the Executive even though the Parliament simply receives the AIReF reports and does not play a role in the activation of the 'comply or explain' procedure. 
To conclude, the three legislatures have exploited the activity of the IFIs to better hold the government into account only to a limited extent, in particular, to ask for justifications or for the corrections of its fiscal and budgetary policy. Based on the case studies examined, the institutional proximity and the regular contact of the IFI (however independent and functionally autonomous) with the parliament do not seem decisive for the strengthening of parliamentary accountability procedures. Despite the fiscal councils' similar powers, no major differences could be detected in this regard between the influence of the AIReF, the IFI with the loosest direct contact with the legislature, the IPBO, and the IFAC somewhat placed in between. Nor do the budgetary powers with which a legislature is equipped appear to determine the way in which parliaments 'make use' of the fiscal councils.

\section{Acknowledgments}

The author would like to thank the editors of this thematic issue, Eric Miklin, Aleksandra Maatsch, and Tomasz P. Woźniakowski for their guidance, Karolina BorońskaHryniewiecka, Carlos Closa Montero, Felipe González De León, and all the participants in the ERC "Leviathan" research project's workshop on "Rising to a Challenge? 10 Years of Parliamentary Accountability of Post-Crisis EU Economic Governance" organized on 10 December 2020 by the Hertie School of Governance for the helpful feedback on a previous version of the manuscript, and the anonymous reviewers for their insightful comments. The usual disclaimer applies.

\section{Conflict of Interests}

The author declares no conflict of interest.

\section{Supplementary Material}

Supplementary material for this article is available online in the format provided by the author (unedited).

\section{References}

Auel, K. (2007). Democratic accountability and national parliaments: Redefining the impact of parliamentary scrutiny in EU affairs. European Law Journal, 13(4), 487-504.

Bateman, W. (2020). Public finance and parliamentary constitutionalism. Cambridge University Press.

Beetsma, R. W. M. J., \& Debrun, X. (2016). IMF working paper. Fiscal councils: Rationale and effectiveness (Working Paper No. 16/86). International Monetary Fund.

Bertelsmann, J. I. (2013). Independent fiscal institutions in the face of rising public indebtedness. In G. Kopits (Ed.), Restoring public debt sustainability: The role of independent fiscal institutions (pp. 75-97). Oxford
University Press.

Bovens, M. (2007). Analysing and assessing accountability: A conceptual framework. European Law Journal, 13(4), 447-468.

Closa, C., De León, F. G., \& Fraga, F. L. (2020). Democracy vs. technocracy: National parliaments and fiscal agencies in the EMU governance. Reconnect. https://reconnect-europe.eu/wp-content/uploads/ 2020/11/D10.2.pdf

Crum, B. (2018). Parliamentary accountability in multilevel governance: What role for parliaments in postcrisis EU economic governance? Journal of European Public Policy, 25(2), 268-286.

Curtin, D. (2014). Challenging executive dominance in European democracy. Modern Law Review, 77(1), $1-32$.

Dicey, A. (2013). Introduction to the study of the law of the Constitution. In J. W. F. Allison (Ed.), The law of the Constitution. Oxford University Press. (Original work published 1885)

Downes, N., \& Nicol, S. (2016). Review of budget oversight by parliament: Ireland. OECD Journal of Budgeting, 1, 66-115.

European Commission. (2012). Communication from the Commission: Common principles on national fiscal correction mechanisms. https://eur-lex.europa.eu/ legal-content/EN/TXT/?uri=CELEX\%3A52012DC0342

European Commission. (2017). Report from the Commission presented under Article 8 of the Treaty on Stability, Coordination and Governance in the Economic and Monetary Union. https://ec.europa.eu/ commission/presscorner/detail/fr/DOC_12_2

European Commission. (2021). Scope index of fiscal institutions 2019 vintage. https://ec.europa.eu/info/ publications/fiscal-institutions-database_en

European Fiscal Board. (2017). 2017 Annual Report. https://ec.europa.eu/info/publications/2017annual-report-european-fiscal-board_en

Fasone, C. (2014). Eurozone, non-eurozone and 'troubled asymmetries' among national parliaments in the EU: Why and to what extent this is of concern. Perspectives on Federalism, 6(3), 1-41.

Fasone, C., \& Griglio, E. (2013). Can fiscal councils enhance the role of national parliaments in the European Union? A comparative analysis. In B. de Witte, H. Héritier, \& A. H. Trechsel (Eds.), The euro crisis and the state of European democracy (pp. 264-305). European University Institute.

Fromage, D. (2017). Creation and reform of independent fiscal institutions in EU member states: Incomplete and insufficient work in progress? In T. Beukers, B. de Witte, \& C. Kilpatrick (Eds.), Constitutional change through euro-crisis law (pp. 108-142). Cambridge University Press.

Griglio, E. (2020). Parliamentary oversight of the executives: Tools and procedures in Europe. Hart Publishing.

Hagemann, R. (2011). How can fiscal councils strengthen 
fiscal performance? OECD Journal: Economic Studies, 1, 75-98.

Horvath, M. (2018). EU independent fiscal institutions: An assessment of potential effectiveness. Journal of Common Market Studies, 56(3), 504-519.

Irish Parliament. (2012). Fiscal Responsibility Act (Act No. 39 of 2012). http://www.irishstatutebook.ie/eli/ 2012/act/39/enacted/en/print.html

Jankovics, L., \& Sherwood, M. (2017). Independent fiscal institutions in the EU member states: The early years (European Economy Discussion Paper No. 067). European Commission.

Kasperskaya, Y., \& Xifré, R. (2018). Assessing the role of Spain's AIReF in the context of EU fiscal policy, Funcas SEFO, 7(3), 60-73.

Maatsch, A. (2017). Effectiveness of the European Semester: Explaining domestic consent and contestation. Parliamentary Affairs, 70(4), 691-709.

Markakis, M. (2020). Accountability in the economic and monetary union: Foundations, policy, and governance. Oxford University Press.

Mezey, M. L. (1979). Comparative legislatures. Duke University Press.

Moschella, M. (2017). When some are more equal than others: National parliaments and intergovernmental bailout negotiations in the eurozone. Government and Opposition, 52(2), 239-265.

Norton, P. (1990). Legislatures in perspectives. West
European Politics, 13, 143-152.

OECD. (2018). AlReF: Spain's independent authority for fiscal responsibility-Highlights. https://www.oecd. org/gov/budgeting/independent-fiscal-institutionsreview-airef-brochure.pdf

Polsby, N. W. (1975). Legislatures. In F. Greenstein, \& N. W. Polsby (Eds.), Handbook of political science (Vol. 5, pp. 1-495). Addison-Wesley.

Ruiz Almendral, V. (2017). The European fiscal consolidation legal framework: Its impact on national fiscal constitutions and parliamentary democracy. In T. Beukers, B. de Witte, \& C. Kilpatrick (Eds.), Constitutional change through euro-crisis law (pp. 27-67). Cambridge University Press.

Tesche, T. (2019). 'The troika is dead, long live the domestic troikas?': The diffusion of national fiscal councils in the European Union. Journal of Common Market Studies, 57(6), 1211-1227.

Viney, C., \& Poole, T. (2019). Independent fiscal institutions. In R. Masterman \& R. Schütze (Eds.), The Cambridge companion to comparative constitutional law (pp. 441-468). Cambridge University Press.

Wehner, J. (2010). Legislatures and the budget process: The myth of fiscal control. Palgrave.

Woźniakowski, T. P., Maatsch, A., \& Miklin, E. (2021). Rising to a challenge? Ten years of parliamentary accountability of the European Semester. Politics and Governance, 9(3), 96-99.

\section{About the Author}

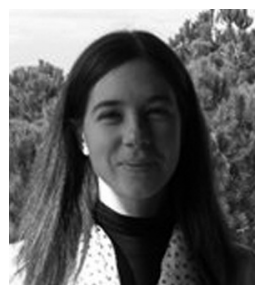

Cristina Fasone (PhD, from the University of Siena) is Assistant Professor of Comparative Public Law at LUISS University, in Rome, and Visiting Professor at Nicolaus Copernicus University of Toruń, Faculty of Law. A member of the steering committee of the ECPR Research Network on Differentiated Integration, she has held a Jean Monnet Module 2016-2019 on "Parliamentary accountability and technical expertise: Budgetary Powers, Information and Communication Technologies and Elections" (PATEU) and has been Max Weber Post-Doctoral Fellow in Law at the European University Institute. 